InVisible Culture • Issue 33: After Douglas Crimp

\title{
After Douglas Crimp \\ Questionnaire Response: \\ Ann Reynolds
}

\section{Ann Reynolds}

Published on: Jan 05, 2022

DOI: $10.47761 / 494 \mathrm{a} 02 \mathrm{f} 6.52 \mathrm{c} 46 \mathrm{dOf}$

License: Creative Commons Attribution 4.0 International License (CC-BY 4.0). 


\section{SHARING TIME IN THE ARCHIVES WITH DOUGLAS}

Douglas and I spent some time together in the archives, but not nearly enough time, as it turned out. Losing someone brings the constant sharing of things and experiences to an end, or at least, renders it one-sided. Alone with my own thoughts, I imagine how Douglas would respond to certain performances and films, or to some of the old letters, diary entries, and personal photographs that I continue to discover through my research, and within that imagining he often flickers into view. Douglas had strong opinions, tastes, and ethical parameters. We did not always agree, especially when it came to some of the artists and critics associated with surrealist circles in New York that I have been thinking and writing about over the past ten years or so. But he recognized and respected a love of things, even if he did not share your love for something in particular.

One winter we agreed to meet at the New York Public Library for the Performing Arts at Lincoln Center to look at materials related to each other's book projects-he was working on what would become his memoir, Beyond Pictures, and I was working on my book, Imagining an Altogether: Cinema, Surrealism, and New York 1940-1970. He wanted me to look at Leonor Fini's drawings of her costume designs for the 1947 Paris Opéra Ballet production of George Balanchine's Symphony in C (originally titled Le palais de cristal), and I wanted him to watch a film of Anthony Tudor's 1943 ballet Dim Lustre that had been shot from the audience by an anonymous fan. He was uneasy about the wildly surrealist qualities of Fini's designs, as he had come to know Symphony in $C$ as one of Balanchine's "Black and White" ballets. I was nervous about writing about choreography as perceived through film. We both needed a pair of less judgmental and more experienced eyes. We had never shared our work in this way before, and it felt, at least to me, quite intimate as we bridged our differing aesthetics and approaches through experiences drawn from our time together watching so many live performances of ballet, among other types of dance and performance over the years. Documents quickly translated into experiential concerns: "How would this outrageous detail not get tangled up in the dancers legs?" or "I wish the head of the person in front of the camera would not keep shifting." We were told to keep our voices down several times. These are the types of questions I still hear Douglas asking when I sift through drawings and letters, or watch films, especially those related to dance. 
About a year ago, I was finally able to read all of the letters Joseph Cornell wrote to the poet and critic, Parker Tyler. Although, for a time, especially during the 1940s, they were quite close, not many letters remain, but each one is filled with allusions to their shared experiences-and love-of ballet, opera, and film, both in the theater and through still images. Cornell confesses to seeing Come Live With Me, starring Hedy Lamarr, "five times through, a fact I'd hate to have many of my friends in on"; he makes suggestions for catching Maria Calla "in the off-stage effect as of deep forest in I PURITANI"; he anticipates sharing gossip after attending rehearsals of the American Ballet, and celebrates their shared love of elaborate pastries: "Too bad your note reached me just as the stores were closing yesterday for G. Washington Week-end, for I could have nabbed me a cream filled roll replete with choc hatchet and maraschino cherry sprig to celebrate the Charlot windfall. In which case memories would have been freshened of my first visit to you-over on Sixth Street in the room with the 'white' decor where you regaled me with a similar confection at tea time,--jelly roll, I believe, or something of the kind." 1 I would love to share these letters with Douglas; I can imagine how he would delight in them.

After we were finished at the library, we walked over to Épicerie Boulud on the corner of Broadway and $64^{\text {th }}$ for some tea and pastries. Douglas took his time picking the pastries out, choosing many more than it seemed possible to consume in one sitting. But Douglas managed to eat most of them. His insatiable sweet tooth always delighted me. It was a very cold, blustery day, but we were animated by what we had seen and certainly by the sugar. At the time, I thought there would be much more of this, and there was some. Thankfully others have put these types of experiences into writing, for me to discover and conjure Douglas, even if just for a few moments at a time

Ann Reynolds is an Associate Professor in the Department of Art and Art History and the Center for Women's and Gender Studies at the University of Texas at Austin.

$\underline{\text { Click here to return to the other questionnaire responses. }}$

\section{Footnotes}

1. Joseph Cornell, letters to Parker Tyler, May 25, 1941; May 22, 1956; and February 22, 1948; Parker Tyler Papers, Harry Ransom Center, Box 7, Folder 3. 